\title{
Altruistic participation in (bio)medical experiments on both sides of the European rabbit borderline
}

\author{
Ger T. Rijkers ${ }^{1,2^{*}}$ and Samuel Max ${ }^{1,3}$ \\ 1 Science Department, University College Rooselvelt, Middelburg, The Netherlands; g.rijkers@ucr.nl \\ 2 Microvida Laboratory for Medical Microbiology and Immunology, St Elizabeth Hospital, Tilburg, The \\ Netherlands; g.rijkers@etz.nl \\ 3 Medical Sciences Division, University of Oxford, Oxford, United Kingdom; samuelmax@live.com \\ * Correspondence: g.rijkers@ucr.nl ; Tel.: +31-6 51751832 (G.T.R.)
}

Simple Summary: In English, a subject of a (biomedical) experiment is termed a "guinea pig". In German the term for such a person is "Versuchskaninchen", a test rabbit. In most European countries and languages either guinea pig or rabbit is used, with a few countries using mouse or rat. The "guinea pig" countries are, apart from the United Kingdom, Ireland, Iceland, France, Spain, Portugal, Italy, and a few Balkan countries. "Rabbit" countries are apart from Germany, The Netherlands, Scandinavia, and most of Eastern Europe including Russia. It is clear that there runs a rabbit borderline through Europe. It is unclear whether "guinea pig" countries love guinea pigs more than rabbits. At any rate, more animal experiments with guinea pigs are performed in "guinea pig" countries. People from "rabbit" countries participate more in (bio) medical experiments and are more often donor of cells and tissues. The motives for doing so are not purely altruistic, because the participants from "rabbit" countries do want something in return.

\begin{abstract}
Background: In the United Kingdom, Ireland, Iceland, France, Spain, Portugal, and Italy a subject participating in a (bio) medical experiment is termed a guinea pig. In Germany (Versuchskaninchen), The Netherlands, all of Scandinavia, and most of Eastern Europe, the term rabbit is used for such a subject. We have searched for potential differences in attitudes towards biomedical research by inhabitants of the respective European countries by making an analysis of frequency and motivation to participate in biomedical experiments on both sides of the European rabbit borderline. (2) Methods: We have performed an analysis of the use of experimental animals for research in European countries as well as country specific scientific output in PubMed indexed literature. Attitudes towards biomedical research in European countries was derived from EU questionnaires. (3) Results: In biomedical experiments with animals, more guinea pigs are used in laboratories in "rabbit countries" than in "guinea pig countries". Inhabitants of "rabbit countries" have a higher participation rate in biomedical experiments and donation of blood than people from "guinea pig" countries. The reasons to participate in a medical experiment are not purely altruistic, especially in "rabbit countries". (4) Conclusions: inhabitants of European countries in which a person who participates in a biomedical experiment is labeled as an (experimental) rabbit participate more in biomedical experiments as well as tissue and organ donation. Motives to do so are not just altruistic, because financial reasons also play a role.
\end{abstract}

Keywords: guinea pig; rabbit; Versuchskaninchen; animals experiments; organ donation; biomedical experiments; altruism 


\section{Introduction}

According to Oxford English Dictionary, a guinea pig is, apart from a rodent mammal of the genus Cavia, also a "person or thing used as the subject of an experiment" [1]. In the German language, the term for such a subject is Versuchskaninchen: "Versuchsperson; jemand, an dem etwas ausprobiert werden soll" [2], in English "Test subject; someone to try something on". A "Versuchskaninchen" in German is a rabbit. Guinea pigs and rabbits clearly are two different animals.

It has been argued that George Bernhard Shaw has been instrumental in coining the term "guinea pig" for a person being subjected to a medical experiment [3]. This started with Robert Koch, who discovered the cause as well as treatment of tuberculosis. Robert Koch inoculated a great number of different experimental animals, including mice, rabbits, rats, even monkeys. Guinea pigs turned out to be most susceptible: as little as 5 bacilli can cause disease and kill the guinea pig [4]. In the extensive foreword to his play A Doctor's Dilemma, Shaw takes a strong anti-vivisectionist standpoint and states ". . if a guinea pig may be sacrificed for the sake of very little that can be learnt from it, shall not a man be sacrificed for the sake of the great deal that can be learnt from him .. ${ }^{6}$. In the same paragraph however, when dealing with the role of clinical and experimental research to find the cause and cure for tuberculosis, Shaw writes "... the doctor, the patients, and the rabbit all suffered in vain .." [5]. Despite Shaw's assertion that both guinea pig and rabbit suffered needlessly, only the guinea pig became the token species. While the above could explain the use of the term guinea pig in English, it would be difficult to follow the same logic for languages of Roman origin including French, Spanish, Portuguese, and Italian. Additionally, Guinea pig usage is spread across countries that speak languages from different families, including certain Germanic countries (English and Icelandic), as well as the aforementioned Roman languages.

The question is whether the clustering into guinea pig and rabbit countries is coincidental, or whether it somehow reflects the attitude towards animal experiments and the willingness of people to participate in biomedical experiments as guinea pigs or Versuchskaninchen for that matter.

\section{Materials and Methods}

The term used in the European languages to describe a subject of an experiment was retrieved using online dictionaries such as Lexilogos (https://www.lexilogos.com/index.htm ), Glosbe (https://en.glosbe.com/), and Linguee (https://www.linguee.com/). Starting with the English "guinea pig", example sentences were checked for context, and thus the correct term (and animal) for a subject of an experiment was identified. In case of ambiguity, scientists from the country and language in question were consulted (see Acknowledgements). Data on the use of animals in biomedical and other experiments were retrieved from official EU publications. Quantitative analysis of scientific publications based in animal experiments in the various European countries was performed with data retrieved from PubMed (https://pubmed.ncbi.nlm.nih.gov/). Search terms were animal species and name of country. Data on location and participants in clinical trials were retrieved from ClinicalTrials.gov (https://clinicaltrials.gov/ ), a database of clinical studies conducted around the world.

\section{Results}

\subsection{Nomenclature of a person as subject in an experiment}

Inspection of the European languages and countries reveals that the majority of countries uses either the word guinea pig or rabbit to describe a person as the subject in an experiment in their local language (Table 1). 
Table 1. Description of a person as the subject in an experiment in European countries and their languages.

\begin{tabular}{|c|c|c|c|c|}
\hline Country & Population & Language(s) & $\begin{array}{l}\text { Term for person as } \\
\text { subject in an experiment }\end{array}$ & Species \\
\hline Albania & 2.870 .324 & Albanian & kavie & rat \\
\hline Austria & 8.857 .960 & German & Versuchskaninchen & rabbit \\
\hline Belarus & 9.477 .100 & Belarussian & эксперыментальны & rabbit \\
\hline Belgium & 11.449 .656 & Multilingual $^{1}$ & & \\
\hline Bosnia and Herzegovina & 3.511 .372 & Multilingual $^{2}$ & zamorče & guinea \\
\hline Bulgaria & 7.000 .039 & Bulgarian & морско свинче & guinea \\
\hline Croatia & 4.105 .493 & Croatian & pokusni kunić & rabbit \\
\hline Cyprus & 8.642 & Bilingual $^{3}$ & & \\
\hline Czech Republic & 10.627.794 & Czech & pokusný králík & rabbit \\
\hline Denmark & 5.806 .015 & Danish & forsøgskanin & rabbit \\
\hline Estonia & 1.328 .976 & Estonian & katsejänes & rabbit \\
\hline Finland & 5.522 .015 & Finnish & koekaniini & rabbit \\
\hline France & 67.076 .000 & French & cobaye & guinea \\
\hline Germany & 82.887 .000 & German & Versuchskaninchen & rabbit \\
\hline Greece & 10.768 .193 & Greek & $\pi \varepsilon\llcorner\varrho \alpha \mu \alpha \tau o ́ \zeta \omega o$ & mouse \\
\hline Hungary & 9.771 .000 & Hungarian & kisérleti nyúl & rabbit \\
\hline Iceland & 35.562 & Islandic & nagris & guinea \\
\hline Ireland & 4.921 .500 & Irish, English & muca guine & guinea \\
\hline Italy & 60.390 .560 & Italian & cavia & guinea \\
\hline Kosovo & 1.798 .506 & Bilingual $^{4}$ & & \\
\hline Latvia & 1.921 .300 & Latvian & jūrascūciṇas & guinea \\
\hline Lithuania & 2.794 .090 & Lithunian & triušis & rabbit \\
\hline Luxembourg & 626.108 & Multilingual $^{5}$ & Mierschwéngchen & guinea \\
\hline Malta & 514.564 & Maltese & og்getti ta' esperiment & objects \\
\hline Moldova & 2.681 .735 & Moldovian & șobolan & rat \\
\hline Montenegro & 622.359 & Montenegran & zamorče & guinea \\
\hline Netherlands & 17.417 .600 & Dutch & proefkonijn & rabbit \\
\hline North Macedonia & 2.075 .301 & Macedonian & заморче & rat \\
\hline Norway & 5.323 .933 & Norwegian & provekanin & rabbit \\
\hline Poland & 38.433 .600 & Polish & królik doświadczalny & rabbit \\
\hline Portugal & 10.276.617 & Portugese & cobaia & guinea \\
\hline Romania & 19.523 .621 & Romanian & sobolan & rat \\
\hline Russia & 146.877.088 & Russian & подопытный кродик & rabbit \\
\hline Serbia & 6.963 .764 & Serbian & zamorce & guinea \\
\hline Slovakia & 5.445 .087 & Slovakian & pokusného králika & rabbit \\
\hline Slovenia & 2.070 .050 & Slovenian & poskusni zajci & rabbit \\
\hline Spain & 46.733 .038 & Spanish & cobaya & guinea \\
\hline Sweden & 10.319 .601 & Swedish & försökskanin & rabbit \\
\hline Switzerland & 8.526 .932 & Multilingual $^{6}$ & & \\
\hline Turkey & 83.154 .997 & Turkish & deney faresi & mouse \\
\hline Ukraine & 41.660 .982 & Ukrainian & піддослідниий кролик & rabbit \\
\hline United Kingdom & 66.796 .807 & English & guinea pig & guinea \\
\hline
\end{tabular}


Moreover, guinea pig countries/languages as well as rabbit countries/languages are clustered, which allows the European rabbit borderline to be drawn (Figure 1). It has to be acknowledged that the Balkan peninsula is a mixed bag, of both guinea pig, rat, and mouse pig countries. In two cases this borderline splits up a country, Belgium and Switzerland. Latvia can be considered a guinea pig enclave surround by rabbit countries (Figure 1).

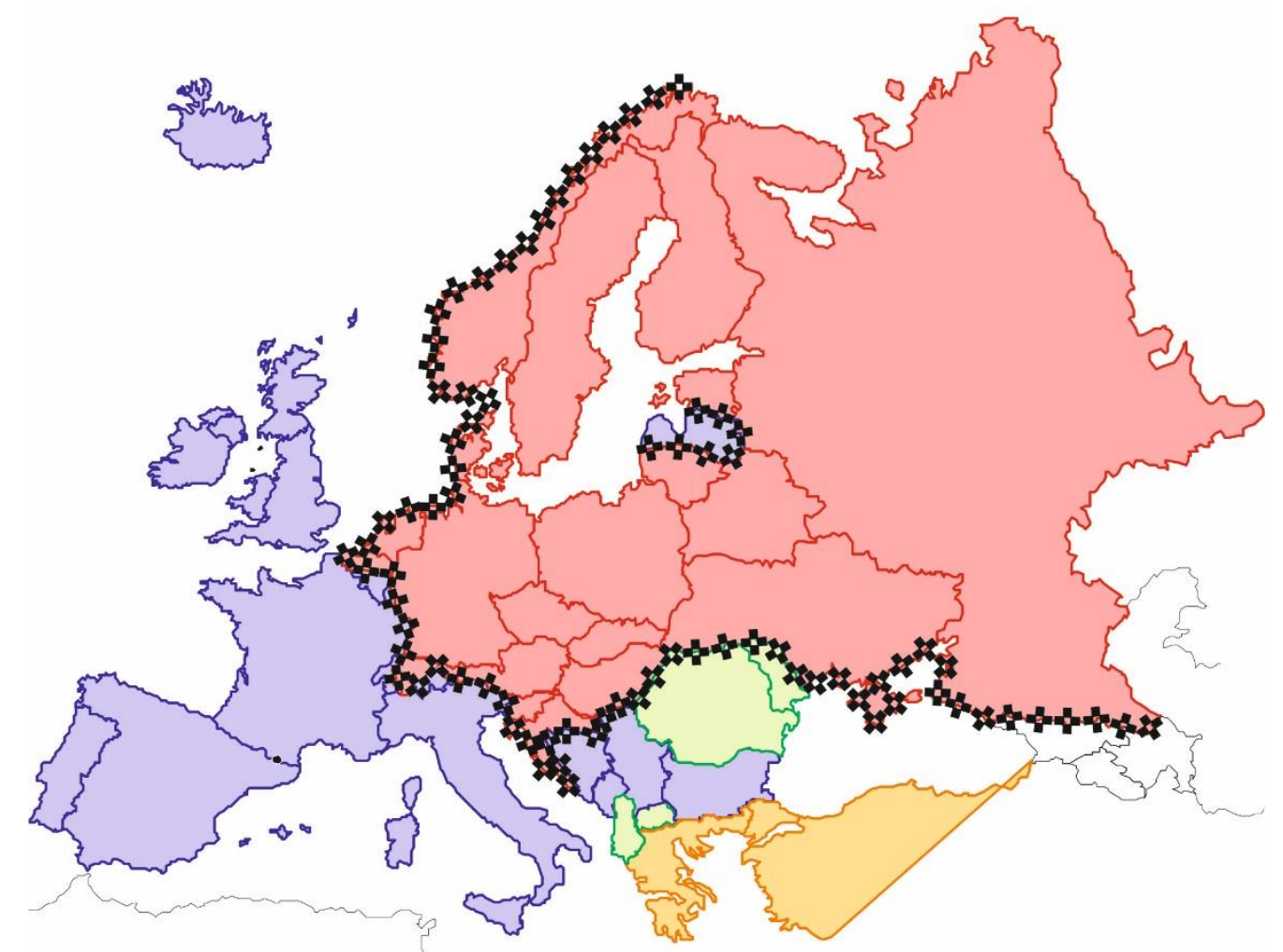

Figure 1. Grouping of European countries based on the term used for a participant in (bio)medical experiments. Countries in blue use the equivalent of the term "guinea pig", countries in red "rabbit". Countries in green use "rat", brown "mice". The rabbit borderline is depicted in black crosses. Georgia and Azerbaijan are considered transcontinental countries.

\subsection{Guinea pigs and rabbits in animal experiments}

In biomedical research in the European Union, over 9 million experimental animals (of which 7.5 million mammals) are used yearly for research, testing, routine production (mainly of blood-based products), and for educational purposes [6]. Mice and rats are the mammalian species most often used (75\% and 15\%, respectively). Rabbits and guinea pigs are in position 3 and 4,respectively on this list, but lag far behind the total numbers of animals used (rabbits $4.6 \%$ of total, guinea pigs $1.9 \%$ ) [6]. The reasons why subjects of research are referred to as guinea pigs or as rabbits in so many languages (rather than mouse or rat) therefore are not immediately evident.

\subsection{Origin of the term guinea pig (and rabbit) for someone participating in an experiment}

When in a given country, for whatever reason, the guinea pig has become the symbol for the animal suffering in medical experiments, it might be expected that guinea pig countries conduct relatively few experiments using guinea pigs. The opposite is true, however. In guinea pig countries, significantly more experiments with guinea pigs are performed than in rabbit countries: 89,000 guinea pigs versus 37,5000 in rabbit countries (Chi square corrected for the total population of the respective country groups $\mathrm{p}<0.0001$ ) [6]. The country which has used most guinea pigs in 
experiments in 2017 is France (45,034 animals) while Finland reported just 9 guinea pigs [6]. With the words of George Bernard Shaw in mind ( ". . for the sake of very little that can be learned from it. . ") it is relevant to analyse the outcome of the guinea pig experiments in terms of scientific publications. In absolute terms, Germany is the country with the most publications on guinea pigs (3116) [7]. This country also is leading in biomedical publications with rabbits for that matter (8055) [7]. Since the mid 1980s, the number of scientific publications based on experiments with guinea pigs has dropped from over 3500 per year in 1989 to 711 in 2019. The reasons for this can be manifold, including financial considerations. The price for an outbred Hartley Guinea pig starts at $£$ 85.28 (weight and sex dependent), for an inbred BALB/c mouse the price starts at $£ 11.30$ [8]. The financial argument was also suggested by George Bernard Shaw, again from the Doctor's Dilemma: ". . it is worth noting that in this case, where both rabbits and men were equally available, the men being of course enormously more instructive and costing nothing, were experimented on first" [6]. In the end, Robert Koch was awarded the Nobel prize in Medicine in 1905. In his acceptance speech he admits that "the struggle against tuberculosis is not dictated from above, and has not always developed in harmony with the rules of science" [9]. George Bernard Shaw had to wait for 20 years (21 actually) before he received the Nobel prize for Literature. A further 42 years later saw the Beatles sing "And for all the little piggies, life is getting worse" [10].

\section{3 (Bio)medical experiments in guinea pig and rabbit countries}

Does the willingness to participate in human (bio)medical experiments differ between people from guinea pig countries and rabbit countries? The European Union has conducted a survey in all member states about attitudes towards cell and tissue donation, both during lifetime and after death [11]. The data from this survey show that rabbit countries have $7.5 \%$ more blood donors (expressed per million population) than guinea pig countries (Figure 2). On the other hand, the number of live kidney donors (expressed per million population) is $4.8 \%$ higher in guinea pig countries. It has to be noted however that the heterogeneity in the fraction of live donors for kidney transplantation is enormous, ranging from $4 \%$ in Poland to $100 \%$ in Iceland [12]. Active participation in a clinical trial is a closer approximation of acting as a guinea pig or Versuchskaninchen. Both the total number of clinical trials, as well as the trials that accept healthy volunteers, is higher in rabbit countries [13].

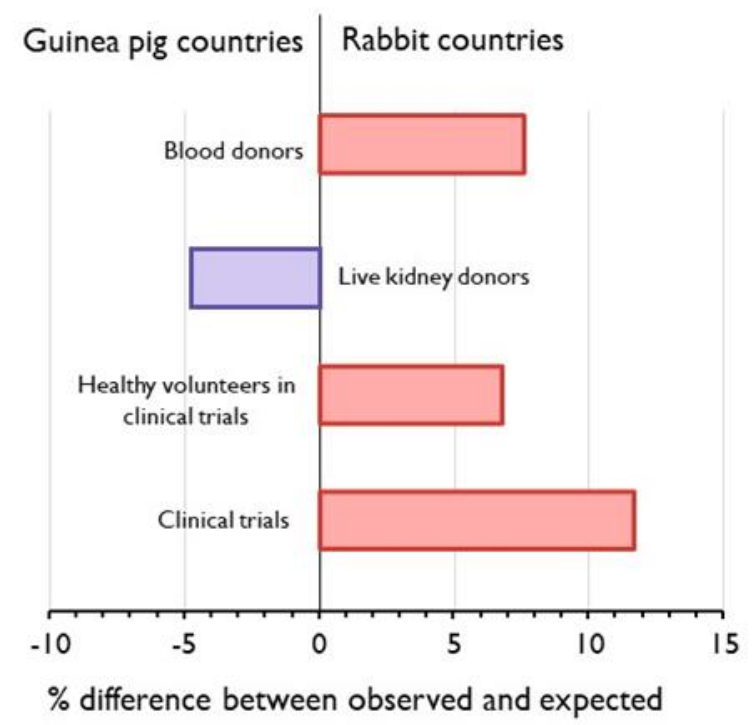


Figure 2. Donation of cells and tissue and participation in medical experiments in guinea pig and rabbit countries. Of the 13,348,174 blood donors in the EU, 7.5\% more were observed in rabbit countries than expected on size of the population as compared to guinea pig countries $(211,329,690$ and $255,875,044$, respectively). Of the 3,676 live kidney donors, $4.8 \%$ more than expected were from guinea pig countries. Of 18,172 clinical trials which accepted participation by healthy volunteers, $6,8 \%$ more than expected were registered in rabbit countries. Of the 149,350 clinical trials in total, $11.7 \%$ more than expected were registered in rabbit countries. Data compiled from public sources indicated in references [11-13].

\subsection{Motivation to participate in experiments}

According to the Bible, Jesus once said "It is more blessed to give than to receive" [14]. For human blood this doesn't hold true. Between $15 \%$ and $40 \%$ of the EU population either is an active blood donor or is willing to donate in the future, but $55-95 \%$ is willing to receive blood should that be needed to treat their own medical condition (Figure 3). No significant differences between guinea pig and rabbit countries are found, although the 3 countries that are most willing to receive blood are rabbit countries: The Netherlands, Denmark and Sweden, in that order.

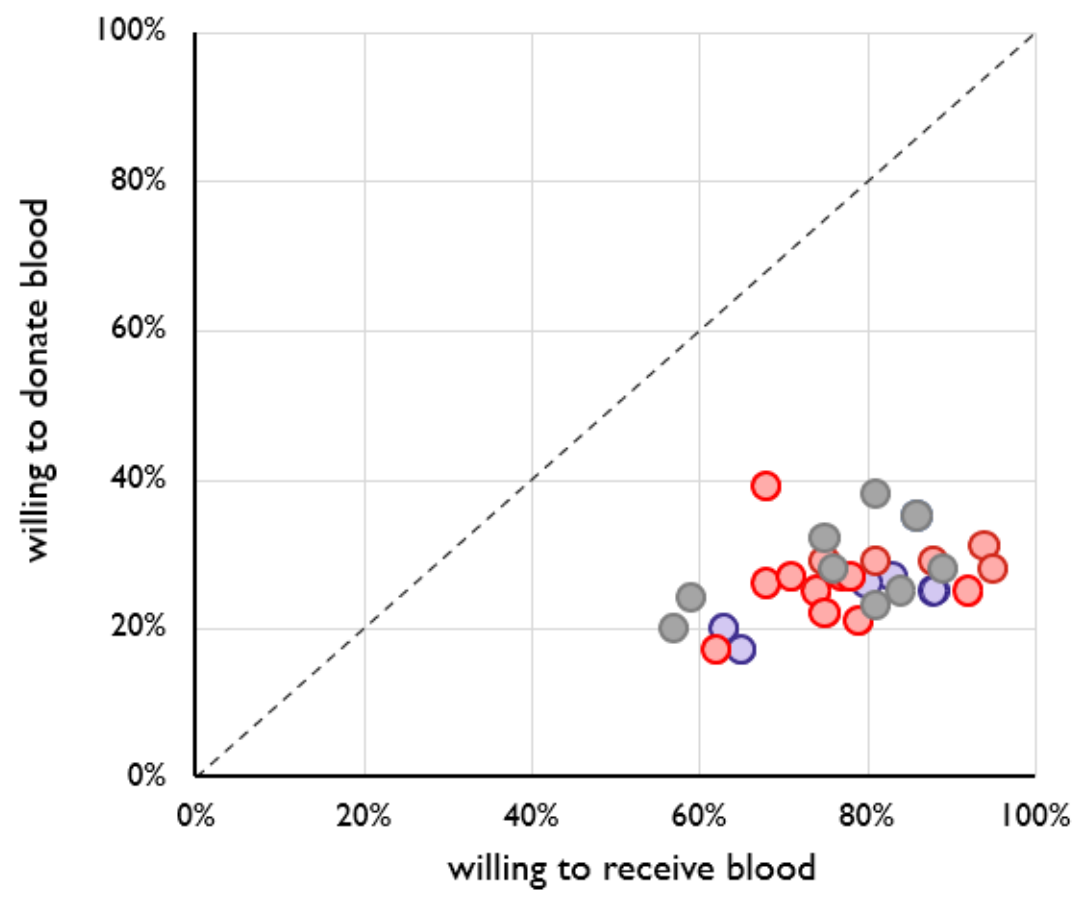

Figure 3. Lack of correlation between preparedness to donate blood and to receive blood. Guinea pig countries in blue, rabbit countries in red. Other EU member states in grey. $R^{2}=0.182, F=6.269$.

It is generally recognized that the quality and safety of blood and blood components can best be guaranteed by voluntary non remunerated blood donation [15]. The EU directive to this effect now has been implemented in virtual every EU member state [16-18]. However, the principle that donors should not be remunerated for their cells and tissues comes under pressure when those cells or tissues serve as starting material for medicinal products or procedures by profit-oriented (pharmaceutical) companies [19]. This especially holds true for oocyte donation. It has been calculated that $300 €$ would be a reasonable compensation for oocyte donation, based on comparison with live organ donation [20]. The financial compensation given actually is much higher, an 
average $675 €$ in the UK, France, Spain, and Portugal and average $750 €$ in Sweden, Finland, Denmark, and The Netherlands [21]. Apart from Finland, all compensations given are above $300 €$.

A shortage of blood products in European countries therefore can and does arise, which then has to be remedied with imported blood products from the US where donors are paid. Although officially non-remunerated, EU countries have been provided with some form of guiding principles concerning the possibility of giving incentives to donors of blood and blood components [22]. What exactly would constitute an acceptable incentive has been the subject of a European survey. The results show a clear difference between inhabitants of guinea pig countries as compared to rabbit countries [23]. These differences are most prominent in their acceptance rate to receive noncash gifts, reimbursement of travel cost, cash for donation related costs, and time off work for the donation and/or recovery, all of which are significantly higher in rabbit countries (see Table 2). Blood donors from both guinea pig as well as rabbit countries in majority consider it acceptable to receive coffee, soft drinks, and snacks.

Table 2. Acceptance rates of incentives given to blood donors in EU member states.

\begin{tabular}{llll}
\hline $\begin{array}{l}\text { Do you consider it } \\
\text { acceptable }\end{array}$ & $\begin{array}{l}\text { Guinea pig } \\
\text { countries }\end{array}$ & Rabbit countries & Significance** \\
\hline $\begin{array}{l}\text { To receive refreshments } \\
\text { (e.g. coffee, soft drinks, } \\
\text { snacks, etc.) }\end{array}$ & $59 \pm 18$ & $58 \pm 17$ & 0.378439 \\
$\begin{array}{l}\text { To receive non-cash items } \\
\text { (e.g. first aid kits, etc.) }\end{array}$ & $13 \pm 4$ & $22 \pm 10$ & $\mathbf{0 . 0 3 1 1 3 5}$ \\
$\begin{array}{l}\text { To receive reimbursement } \\
\text { of travel costs* }\end{array}$ & $26 \pm 4$ & $\mathbf{0 . 0 0 3 1 5}$ \\
$\begin{array}{l}\text { To receive cash amounts on } \\
\text { top of reimbursement of }\end{array}$ & $8 \pm 2$ & $40 \pm 11$ & $\mathbf{0 . 0 0 5 1 8 9}$ \\
$\begin{array}{l}\text { the costs related to the } \\
\text { donation }\end{array}$ & & $19 \pm 9$ & \\
$\begin{array}{l}\text { To receive time off work } \\
\text { for the time needed for the } \\
\text { donation and } \backslash \text { or for } \\
\text { recovery) }\end{array}$ & $30 \pm 9$ & & \\
\hline
\end{tabular}

* travel costs are reimbursed up to a maximum of $30 €$ in Spain, up to $470 €$ in Croatia. ${ }^{* *}$ Significance of differences calculated by Chi-square, $\mathrm{p}$ values $<0.05$ indicated in bold.

\section{Discussion}

Our analysis shows that most countries and languages in Europe use either the term "guinea pig" or "Versuchskaninchen" to describe a subject of a (biomedical) experiment. Although the vast majority of animal experiments are performed with mice and rats, just a few countries and languages refer to those species. The geographical clustering of guinea pig countries and rabbit countries cannot readily be explained. English and German (as well as all Scandinavian languages and Dutch) all are Germanic languages but they are separated by the rabbit borderline. 
The comparison of altruistic and other motives to participate in (bio) medical experiments between people living in guinea pig countries and rabbit countries was greatly facilitated by EU wide studies, some of which were cited above. For that reason, little information is available about countries such as Norway, but also Russia, Belarus, and the Ukraine. Switzerland would otherwise also be difficult because of a mixture of guinea pig and rabbit languages. Belgium, geographically located between France (guinea pig) and The Netherlands (rabbit), as an official trilingual country also had to be excluded. It is however interesting to note that in Belgium, $37 \%$ of respondents indicated that they had not donated blood in the past but would be prepared to do so in the future. This number is exact midpoint between the corresponding figures in France $(27 \%)$ and The Netherlands (46\%).

Current attitudes towards the medical sciences and experiments involving humans may change in the future, due in part to the testing and introduction of a SARS-CoV-2 vaccine, genome editing, life extension therapies, and other developments. Future EU guidelines and legislature on organ and tissue donation and on participation in medical experiments no longer will apply to a major guinea pig country in Europe. Time will tell whether this will lead to a change in altruistic behavior.

Author Contributions: Conceptualization, GTR.; methodology, GTR and SM; formal analysis, GTR; investigation, GTR and SM.; writing-original draft preparation, GTR and SM.; writing - review and editing, GTR and SM; visualization, GTR; supervision, GTR. Both authors have read and agreed to the published version of the manuscript.

Funding: This research received no external funding.

Acknowledgments: We want to thank the following people for helping us out with establishing the status of their country of origin as being guinea pig, rabbit or otherwise: Jūrate Skerniškytè, Vilnius, Lithuania; Viktor Szegedi, Szeged, Hungary; Dumitru Chesov, Chisinau, Republic of Moldova. Bert van den Brink, Edward Nieuwenhuis, Ilke Ercan and Frans van Overveld are colleagues at University College Roosevelt, Middelburg, who provided critical input on the pre-final version of the manuscript.

Conflicts of Interest: The authors declare no conflict of interest.

\section{References}

1. Oxford English Dictionary, online edition. https://oed.com (assessed on 25 July 2020)

2. Duden Onlinewörterbuch, https://www.duden.de/woerterbuch (assessed on 25 July 2020)

3. Bynum B. Guineapig. Lancet. 2008;372(9633):107. doi:10.1016/S0140-6736(08)61019-3

4. Wiegeshaus EH, McMurray DN, Grover AA, et al. Host-parasite relationships in experimental airborne tuberculosis. 3. Relevance of microbial enumeration to acquired resistance in guinea pigs. Am Rev Respir Dis 1970; 102: 422-429.

5. Shaw GB. 1906 A Doctor's Dilemma. http://www.online-literature.com/george_bernard_shaw/doctorsdilemma/0/ (assessed on 25 July 2020)

6. Report from the Commission to the European Parliament and the Council. 2019. 2019 report on the statistics on the use of animals for scientific purposes in the Member States of the European Union in 20152017. https://op.europa.eu/en/publication-detail/-/publication/04a890d4-47ff-11ea-b81b-01aa75ed71a1 (assessed on 25 July 2020)

7. National Library of Medicine. PubMed.gov. https:/pubmed.ncbi.nlm.nih.gov/ ?term=guinea+pig+germany\&sort=date\&size $=100 \quad$ (assessed on 3 August 2020)

8. Charles River 2020 Catalogue Research Models and Services United Kingdom; https://www.criver.com/products-services/research-models-services/research-models-servicescatalog?region=3611 (assessed 2 August 2020)

9. Koch R. The Current State of the Struggle against Tuberculosis. Nobel Lecture, December 12, 1905 https://www.nobelprize.org/prizes/medicine/1905/koch/lecture/ (assessed 2 October 2020) 
10. The Beatles. Little Piggies. https://www.thebeatles.com/song/piggies (assessed on 2 October 2020)

11. Eurobarometer 82.2 Special Eurobarometer 426 Blood and Cell and Tissue Donation. https://ec.europa.eu/health/blood tissues organs/eurobarometers/eb822 en (assessed on 2 July 2020)

12. European Renal Association and European Dialysis and Transplantation Association. Annual Report 2017. Amsterdam UMC, location AMC, Department of Medical Informatics, Amsterdam, the Netherlands, 2019. https://era-edta-reg.org/files/annualreports/pdf/AnnRep2017.pdf (assessed on 7 July 2020)

13. U.S. National Library of Medicine. ClinicalTrials.gov https://clinicaltrials.gov/ (assessed on 25 July 2020)

14. Acts 20:35, Bible Gateway. https://www.biblegateway.com/passage/?search=Acts $+20 \% 3 \mathrm{~A} 35 \&$ version=ESV (assessed on 5 August 2020)

15. Heier HE. The history and significance of voluntary, non-remunerated blood donation. Hektoen International 2020; 12(3). https://hekint.org/2020/01/24/the-history-and-significance-of-voluntary-nonremunerated-blood-donation/

16. Directive 2002/98/EC of the European parliament and of the Council of 27 January 2003 setting standards of quality and safety for the collection, testing, processing, storage and distribution of human blood and blood components and amending Directive 2001/83/EC. https://ec.europa.eu/health//sites/health/files/files/eudralex/vol-1/dir_2002_98/dir_2002_98_en.pdf

17. Article 2 of recommendation No. R (95) 14 of the Committee of Ministers to member states on the protection of health of donors and recipients in the area of blood transfusion (Adopted by the Committee of Ministers on 12 October 1995 at the 545th meeting of the Ministers' Deputies); https://wcd.coe.int/com.instranet.InstraServlet?command=com.instranet.CmdBlobGet\&InstranetImage=5 $36539 \&$ SecMode $=1 \&$ DocId $=527032 \&$ Usage $=2$

18. WHO standpoint: WHO Expert Group. Expert Consensus Statement on achieving self-sufficiency in safe blood and blood products, based on voluntary non-remunerated blood donation (VNRBD). Vox Sang. 2012 Nov;103(4):337-42. doi: 10.1111/j.1423-0410.2012.01630.x.

19. Dufner A. Blood Products and the Commodification Debate: The Blurry Concept of Altruism and the 'Implicit Price' of Readily Available Body Parts. HEC Forum 2015;27:347-59. doi: 10.1007/s10730-014-9260-6

20. Kool E, van der Graaf R, Bos A, Fauser B, Bredenoord A. What constitutes a reasonable compensation for non-commercial oocyte donors: an analogy with living organ donation and medical research participation. J Med Ethics 2019;45:736-741. doi: 10.1136/medethics-2019-105474

21. Pennings G, de Mouzon J, Shenfield F, et al. Socio-demographic and fertility-related characteristics and motivations of oocyte donors in eleven European countries. Hum Reprod. 2014;29:1076-89. doi: 10.1093/humrep/deu048

22. 2nd Report from the Commission to the European Parliament, the Council, the Economic and Social Committee and the Committee of the regions on voluntary unpaid blood donations of blood and blood components COM (2011) $138 \quad$ final. $\underline{\text { https:/ec.europa.eu/health/sites/ }}$ health/files/blood_tissues_organs/docs/blood_reportdonation_en.pdf

23. EU Open Data Portal. Special Eurobarometer 426: Blood and Cell and Tissue Donation. 2015. https://data.europa.eu/euodp/en/data/dataset/S2030_82_2_426_ENG/resource/6bfb563a-fa10-4599-aa9af17d17fc5179 